\title{
Intensity of attack, displacement and verbal aggression'
}

DONALD L. WOSHER and LUIS M. PROE:VZA, ${ }^{2}$ Department of Piychology, University of Connecticut. Storrs, Conn. 06_68

One hundred-fifty male college students participated in a laboraton studv of verbal aggression in which they competed against confederates (Cs) while assembling a formboard. The Ss or Cs verbally attacked one another while their opponent was assembling the formboard. Intense verbal attack by a $C$ led to a higher outburst of aggression than did mild verbal attack or no prior attack by a C. Retaliatory verbal attack against a $C$ who had previously attacked the $S$ led to higher peak aggression than conditions in which the $S$ was attacked by one $C$ but displaced his attack to a second $C$.

Mosher, Mortimer, \& Grebel (1968) reported the results of two experiments with delinquent boys using a laboratory measure of verbal aggression. Delinquent boys competed in assembling a formboard for a prize of a package of cigarettes. While their opponent assembled the formboard, they were permitted to say anything they wished to distract, upset or anger their opponent to hamper his performance. These samples of verbal aggression were tape recorded and scored in $10 \mathrm{sec}$ intervals for verbal aggression. In the first experiment, 80 delinquent boys were subjected either to intense or mild verbal attack by delinquent accomplices. The intense verbal attack led to a higher level of retaliatory verbal ageression than did the mild attack. In the second experiment, 128 delinquent boys competed against one another in pairs which pitted boys who were nominated as either powerful or weak against one another. The results supported the prediction that the weak boys would aggress less against powerful "bullies" than against powerful nonaggressive boys, presumably because of a differential fear of retaliation. There were significant differences in verbal aggression as a function of attacker (powerful boys were more aggressive than weak boys), target (weak boys received more verbal aggression than powerful boys), and order of attack (boys attacking first were less aggressive than boys attacking second).

The advantages of a laboratory measure of aggression are well known (Buss, 1961). Indirect measures such as questionnaires or even direct measures which involve administering electric shock to a victim may not form a functional unity with the aggressive behavior of everyday life such as fighting, swearing, and arguing. The laboratory measure of verbal aggression developed by Mosher is highly involving and believable with delinquent boys. The present experiment examined the usefulness of the technique with college males who are more sophisticated about experiments and who may display "company manners" and greater concern about the "artificiality" of the laboratory. The experimental variables of interest involved varying prior attack vs no prior attack, two levels of intensity of prior attack, and retaliatory vs displaced target on verbal aggression.

\section{Design}

\section{METHOD}

The experiment was designed as a 2 by 2 by $2+2$ incomplete factorial design with $15 \mathrm{Ss}$ in each of the 10 cells. Eight cells comprised a 2 by 2 by 2 factorial design in which the Ss were attacked by one of two confederates while they assembled the formboard first. These Ss received either an intense or mild verbal attack, by either Confederate 1 (C 1) or Confederate 2 (C 2), and they then aggressed against the same confederate (retaliation) or against the other confederate (displacement). In the two cells, the Ss made the initial attack against either $\mathrm{C} 1$ or $\mathrm{C} 2$, and thus had not been instigated to verbal aggression by prior attack.

Procedure

The 150 male Ss participated in the experiment as part of their course requirements in introductory psychology. Ss were randomly assigned to the 10 cells.

When the Ss arrived at the laboratory they were told that we were studying competitive success in psychology and business students (the confederates). "It appears that the successful competitive man possesses two essential abilities. First, he is able to work well under all forms of stress. Particularly, he is able to tolerate interpersonal forms of stress-such as when a boss criticizeshim severely or a superior of ficer reprimands him. Secondly, the successful person appears to be able to create stress in others whether it is for personal advancement or for training others to withstand the stress they are likely to encounter." The formboard task was then explained following instructions in Mosher, Mortimer, \& Grebel (in press).

In two cells the Ss attacked either $\mathrm{C} 1$ or $\mathrm{C} 2$ first and the experiment was terminated. In eight cells the Ss assembled the formboard first while receiving either an intense or a mild verbal attack from either $C 1$ or $C 2$. In the four retaliatory cells, the $S$ and $C$ then changed places and the $S$ attacked the same $C$. In the four displacement cells, the $S$ attacked the other $C$ who had supposedly been run in the same task by another $E$ in an adjacent room.

The Cs were trained to assemble the formboard in an awkward manner and to match or do slightly worse than their opponents. The Cs were trained to give identical intense and mild verbal attacks. Using the measure for scoring verbal aggression, the mean aggression level of the intense attack was 4.50. It included 10 statements, half involving Stereotypic Derogation (Level 4) and half involving Stereotypic Derogation With Cursing (Level 5). Examples are:

Level 4: "I don't like the way you look either. You just don't seem right to me. There is something about you that really gets me."

Level 5: "You ignorant bastard. Don't you have a brain in your ass to see it's all wrong. Jesus, that is pretty damned stupid."

The mean level of aggression of the mild attack was 2.50 , and it also contained 10 statements, half of which were Continuous Distraction (Level 2) and half Criticism (Level 3). Examples are:

Level 2: "Let's move it. That's not supposed to go there. That one doesn't go there either. Don't you know where that one goes?"

Level 3: "You really should be able to do better than that. Haven't you ever done this before? Maybe a magnifying glass would help."

The number of pieces assembled in $2 \mathrm{~min}$ was recorded. Ss were debriefed following the experiment.

The $2 \mathrm{~min}$ samples of verbal aggression were tape recorded. The tapes were scored in $1210 \mathrm{sec}$ intervals using a scoring manual which distinguishes 10 levels of verbal aggression ranging along a dimension from silence, to intermittent and continuous distraction, to criticism, to stereotypic derogation without and with cursing, to severe derogation without and with cursing, to stream of profanity, to threat of physical attack. ${ }^{3}$ A Pearson correlation between two raters on a sample of 25 protocols was .98 demonstrating very high interrater reliability. RESULTS

The total verbal aggression score which consisted of the sum of the 12 aggression scores for each $10 \mathrm{sec}$ interval was subjected to an analysis of variance using a modified factorial design. The analysis revealed no significant differences between groups.

The means and standard deviation of the peak aggression score which was the highest aggression score for any one of the 1210 sec intervals are contained in Table 1 . A modified factorial analysis of variance yielded no significant interactions and three significant main effects. The Ss who had received a prior attack from the Ss were significantly more aggressive than $S s$ who had not been attacked prior to attacking the Cs $(F=17.41$, df $=1 / 145$, $\mathrm{p}<.001)$. Ss who had received an intense verbal attack from the Cs were more verbally aggressive than Ss who received a mild verbal attack from the $\mathrm{Cs}(\mathrm{F}=30.18, \mathrm{df}=1 / 145, \mathrm{p}<.001)$. The $S$ s who retaliated against the same $C$ that had attacked them were more verbally aggressive than were the $S s$ who displaced their verbal aggression against a different $C(F=5.54, \mathrm{df}=1 / 145$, 
Table I

Means and Standard Deviations of Peak Verbal Aggression Scores

\begin{tabular}{|c|c|c|c|c|c|}
\hline & \multicolumn{2}{|c|}{ Intense Attack } & \multicolumn{2}{|c|}{ Mild Attack } & \multirow{2}{*}{$\begin{array}{l}\text { No } \\
\text { Prior } \\
\text { Attack }\end{array}$} \\
\hline & $\begin{array}{l}\text { Retali- } \\
\text { ation }\end{array}$ & $\begin{array}{l}\text { Displace- } \\
\text { ment }\end{array}$ & $\begin{array}{l}\text { Retali- } \\
\text { ation }\end{array}$ & $\begin{array}{l}\text { Displace- } \\
\text { ment }\end{array}$ & \\
\hline \multicolumn{6}{|c|}{ Confederate $1^{*}$} \\
\hline Mean & 4.93 & 3.80 & 3.33 & 2.93 & 2.66 \\
\hline $\mathrm{SD}$ & 1.67 & .78 & .82 & .96 & 1.05 \\
\hline \multicolumn{6}{|c|}{ Confederate 2} \\
\hline Mean & 4.33 & 3.93 & 3.20 & 3.33 & 3.00 \\
\hline SD & 1.54 & .88 & .56 & .90 & .65 \\
\hline
\end{tabular}

* As tabled, the confederate is classified as the attacker rather than the target

$p<.05)$. There was not a significant main effect of confederates whether considered as attackers or as targets. Subsequent analysis of the means indicated that the difference between prior attack and no prior attack was primarily a function of the Ss who received an intense verbal attack. There was not a significant difference between the no prior attack mean and the mild verbal attack mean.

The Ss who received a high verbal attack assembled a mean of 7.72 pieces while the Ss who received a low verbal attack assembled a mean of 8.73 pieces during their $2 \min (F=3.39$, $\mathrm{df}=1 / 118, \mathrm{p}<.10$ ). Ss were divided at the median on the number of pieces they assembled in $2 \mathrm{~min}$ and the level of prior attack they had received to form a 2 by 2 factorial design in which the peak aggression score was the dependent variable. The mean of the High Attack-Many Pieces was 3.87, the High Attack-Few Pieces was 4.63, the Low Attack-Many Pieces was 3.27, and the mean of the Low Attack-Few Pieces was 3.13. The interaction between pieces assembled and level of attack was significant $(F=6.92$, $\mathrm{df}=1 / 116, p<.01)$ and was a function of the aggression producing effect of high attack on the Ss who assembled few pieces of the formboard. The main effect of attack was, of course, significant $(F=37.70, \mathrm{df}=1 / 116, \mathrm{p}<.001)$ while the main effect of pieces did not reach an acceptable level of significance $(F=3.43, \mathrm{df}=1 / 116, p<.10)$.

\section{DISCUSSION}

The highest mean total verbal aggression score of the 10 groups of college males was 34.33 which exceeds only 1 of the 16 means of the delinquent boys in Mosher, Mortimer, \& Grebel (1968). The modal verbal aggression of college men was either distraction or criticism which is nonpersonal and task-focused. They dropped their "company manners" only briefly, usually near the beginning of the $2 \mathrm{~min}$, when they became personally derogating and often swore at their opponent. It was the differences between these outbursts of peak aggression and not their average level of verbal aggression which resulted in the significant findings.

The results indicated that an initial intense attack lead to higher peak aggression than an initial mild attack or no prior attack. These data are consistent with the difference between levels of attack in Experiment 1 and the difference between order of attack in Experiment 2 of Mosher, Mortimer, \& Grebel (1968). The significant difference between peak aggression which was retaliatory rather than displaced to a different target indicated that there was a lessening of peak aggression when the original instigator to aggression was not present but a substitute target was. It should be noted that if the $S$ received an intense verbal attack and then displaced his aggression against a different target, his peak aggression was significantly higher than that of Ss who had not received a prior attack. A person instigated to aggression by an intense attack is more aggressive against a displaced target than a person for whom aggression is instrumental in success but who had not been instigated toward aggression by attack. The last finding of interest was that a combination of intense attack and doing poorly at assembling the formboard instigated the greatest peak aggression. While the empirical finding is of interest, it is not possible to distinguish between such plausible explanations as doing poorly on the formboard is frustrating or that intense attack creates anger which interferes with formboard manipulation.

The laboratory measure of verbal aggression appears to have some usefulness with college males, but it does not surmount many of the problems of "playing it cool" while one is a $S$ in a psychological experiment. The results provide clear and direct evidence for a displacement effect of verbal aggression in a face-to-face situation.

\section{REFERENCES}

BUSS, A. H. The psychology of aggression. New York: John Wiley, 1961. MOSHER, D. L., MORTIMER, R. L., \& GREBEL, M. Verbal aggressive behavior in delinquent boys. Journal of Abnormal Psychology, in press.

\section{NOTES}

1. This research was supported by a grant from the University of Connecticut Research Foundation. We wish to thank John McDuff and Lawrence Schlegel for their conscientious assistance as confederates.

2. Now at the University of Minnesota.

3. Copies of the scoring manual are available upon request from the first author. 